\title{
INFLUENCE OF BEDROCK GEOLOGY AND TREE SPECIES COMPOSITION ON STREAM NITRATE CONCENTRATIONS IN MID-APPALACHIAN FORESTED WATERSHEDS
}

\author{
KARL W. J. WILLIARD ${ }^{1, *}$, DAVID R. DEWALLE ${ }^{2}$ and PAMELA J. EDWARDS ${ }^{3}$ \\ ${ }^{1}$ Department of Forestry, Southern Illinois University, Carbondale, IL 62901-4411, U.S.A.; ${ }^{2}$ School \\ of Forest Resources and Penn State Institutes of the Environment, Pennsylvania State University, \\ University Park, PA 16802, U.S.A.; ${ }^{3}$ USDA Forest Service, Northeastern Research Station, Parsons, \\ WV 26287-0404, U.S.A. \\ (*author for correspondence, e-mail: williard@ siu.edu, Tel: (618) 453 7478, Fax: (618) 453 7475)
}

(Received 23 December 2003; accepted 16 July 2004)

\begin{abstract}
Although the large variations in nitrate export from forested watersheds have been attributed to a variety of natural and disturbance-related factors, baseflow nitrate concentrations in 49 mid-Appalachian forested watersheds were most strongly related to differences in bedrock geology. Within the mid-Appalachian region of Pennsylvania, Maryland and West Virginia, watersheds dominated by Pottsville and Allegheny sandstone (PVA), Catskill, Chemung, and Pocono shale and sandstone (CCP), and Mauch Chunk shale and Greenbrier limestone (MCG), respectively, exhibited significantly different low, intermediate, and high mean stream nitrate concentrations. Soil $\mathrm{pH}$, soil percent $\mathrm{N}$ concentration $(\% \mathrm{~N})$, soil $\mathrm{C}: \mathrm{N}$ mass ratio, soil exchangeable $\mathrm{Ca}$, watershed slope, and the occurrence of white ash (Fraxinus americana L.), sugar maple (Acer saccharum Marsh.), and eastern hemlock (Tsuga canadensis L.) were related significantly to bedrock geology type as well as stream nitrate levels. Other factors such as past land disturbances (fire and agriculture) and stand age (oldgrowth) typically were associated with only one bedrock geology type. However, within a bedrock geology type, past agriculture and the presence of old-growth forest may be important in explaining stream nitrate concentrations on an individual watershed basis. The basal area of black locust (Robinia pseudoacacia L.), a species that enhances soil nitrogen levels via nitrogen fixation, showed a moderate positive correlation with stream nitrate concentrations. Bedrock geology explained the most variation in winter $(49 \%)$ and summer $(32 \%)$ stream nitrate concentrations. Bedrock geology may have been a better predictor of stream nitrate concentrations than soil chemistry, because the geologic variation was better assessed at the regional scale of this study compared to soil chemistry, which varies at the micro-scale due to topographic, vegetation, microbial, and climatic influences. Results of this study suggest that bedrock geology is an important factor to consider when assessing forest nitrogen dynamics at a broad landscape scale.
\end{abstract}

Keywords: agriculture, black locust (Robinia pseudoacacia L.), C:N ratio, fire, forest, land-use history, old-growth, nitrate leaching, nitrogen saturation, water quality

\section{Introduction}

Significant regional variability in stream nitrate export exists among midAppalachian forested watersheds. DeWalle and Pionke (1996) reported that nitrate export varied by as much as $500 \%$ among forested watersheds in the region. Many factors have been cited to explain differences in nitrate export at watershed and

Water, Air, and Soil Pollution 160: 55-76, 2005.

(c) 2005 Springer. Printed in the Netherlands. 
regional scales, including differences in wet and dry atmospheric nitrogen deposition (Johnson and Lindberg, 1992; Dise and Wright, 1995; Aber et al., 2003), soil nitrogen cycling processes and soil chemistry (Goodale and Aber, 2001; Lovett et al., 2002; Ollinger et al., 2002), forest species composition (Van Miegroet and Cole, 1984; Binkley and Valentine, 1991; Lewis and Likens, 2000; Lovett et al., 2000), stand age (Vitousek and Reiners, 1975; Goodale and Aber, 2001), past land disturbance history (Raison, 1979; Alriksson and Olsson, 1995; Compton and Boone, 2000; Goodale et al., 2000), and insect defoliation (Swank et al., 1981; Webb et al., 1995; Eshleman et al., 1998; Drohan and DeWalle, 2002).

In the most comprehensive assessment of nitrogen cycling in North America, the Integrated Forest Study (IFS), Johnson and Lindberg (1992) reported that atmospheric nitrogen deposition rates explained only $11 \%$ of the variation in nitrate leaching from 16 watersheds. Williard et al. (1997) found that atmospheric deposition rates were not important in explaining differences in nitrate export from mid-Appalachian forested watersheds. Even though atmospheric wet and dry nitrogen deposition rates are relatively high in the mid-Appalachian region (9.2-11.1 $\mathrm{kg} \mathrm{N} \mathrm{ha}^{-1}$ per year), they do not differ greatly from West Virginia to northwestern Pennsylvania where regional differences in nitrate export were observed (Williard et al., 1997). Lovett et al. (2000) also found that variations in stream nitrate concentrations were not attributable to differences in atmospheric deposition in the Catskill Mountains of southeastern New York. However, atmospheric nitrogen deposition still plays an important role in the nitrogen cycling of these forested watersheds, since chronic nitrogen deposition is the dominant external input of nitrogen into these ecosystems, especially in the northeastern United States.

Johnson and Lindberg (1992) found that soil nitrogen mineralization rates explained the most variation (44\%) in nitrate export from forested IFS watersheds. Controls of soil mineralization rates include soil moisture content, temperature, C:N ratios, and pH (Alexander, 1977; Paul and Clark, 1996). These factors, in turn, are controlled by other ecosystem conditions. Soil moisture and temperature are controlled by climatic and topographic conditions. Soil C:N ratios are affected by overstory vegetation type and stand age, amount of $\mathrm{N}$-fixation, and past land disturbances. Soil pH is controlled by the buffering capacity of the soil, which is influenced by bedrock geology and biogeochemical processes.

Of these underlying potential causes of stream nitrate variation, bedrock geology, past land disturbance (fire, agriculture, and logging), forest species composition, and stand age were included in the experimental design of this study. Variability in stream $\mathrm{pH}$, specific electrical conductance (SEC), base cation concentrations, and alkalinity have been attributed to differences in bedrock geology (Johnson and Reynolds, 1977; Ponce et al., 1979; Silsbee and Larson, 1982), though little research has examined stream nitrate and bedrock geology relationships (Dahlgren, 1994; Holloway et al., 1998). In some areas of the western United States, bedrock has been shown to be a source of nitrogen, in the form of ammonium incorporated into the interlayer of minerals (muscovite and sericite) (Dahlgren, 1994; 
Holloway et al., 1998). We hypothesize that bedrock geology may be related to stream nitrate through its control on soil fertility, and thus soil nitrogen cycling, not direct inputs of nitrogen from bedrock as in the western United States.

Severe fires can affect long-term forest nitrogen cycling by volatilizing significant amounts of soil nitrogen (Gagnon, 1965; Grier, 1975; Raison, 1979; Hornbeck and Lawrence, 1996). Past agriculture can result in depleted or enriched long-term soil nitrogen pools depending on the degree and types of fertilization and tillage practices (Alriksson and Olsson, 1995; Compton and Boone, 2000). Logging can increase nitrate leaching to streams by reducing stand uptake rates of nitrogen and by disturbing upper soil horizons, thereby stimulating nitrogen mineralization and nitrification rates (Huttl and Schaaf, 1995). However, logging effects on stream nitrate levels are generally short term, 1-4 years, in the Appalachians (Hornbeck et al., 1987; Lynch and Corbett, 1991; Dahlgren and Driscoll, 1994; Pardo et al., 1995). Stand age can affect nitrate leaching because young aggrading forests generally have greater nutrient demands and nitrogen uptake rates than mature stands (Vitousek and Reiners, 1975).

Identifying ecosystem variables controlling stream nitrate variation could facilitate the regional estimation of stream nitrate export from forest land. In this study, we examined the contributions of (1) bedrock geology, (2) soil chemistry [e.g. $\mathrm{pH}$, percent $\mathrm{N}$ concentration $(\% \mathrm{~N})$, percent $\mathrm{C}$ concentration $(\% \mathrm{C}), \mathrm{C}: \mathrm{N}$ mass ratio, $\mathrm{P}$, and base cations], (3) past land disturbance (e.g., fire, agriculture, and logging), (4) stand age (5) overstory vegetation type, and (6) physiographic parameters (e.g., average basin slope and watershed aspect) toward explaining stream nitrate concentrations in 49 mid-Appalachian forested watersheds.

\section{Methods}

\subsection{STUDY SITES}

The 49 watersheds were located in three regions of the mid-Appalachians: northwestern Pennsylvania (NW PA), southwestern Pennsylvania (SW PA), and northern West Virginia and western Maryland (WV MD) (Figure 1, Table I). The watersheds are $100 \%$ forested with no major disturbances during the past 60 years. Most of the watersheds are relatively small $\left(<6 \mathrm{~km}^{2}\right)$ and contain first or second-order streams (Table I). Predominant overstory species across the three regions were sugar maple (Acer saccharum Marsh.), black cherry (Prunus serotina L.), and eastern hemlock (Tsuga canadensis L.).

Watersheds were grouped into three geologic categories: Pottsville and Allegheny sandstone (PVA), Catskill, Chemung, and Pocono shale and sandstone (CCP), and Mauch Chunk shale and Greenbrier limestone (MCG) (Figure 1, Table I), based on relative differences in published bedrock fertility and groundwater $\mathrm{pH}$ values. PVA, CCP, and MCP bedrock types, respectively, exhibit low, 


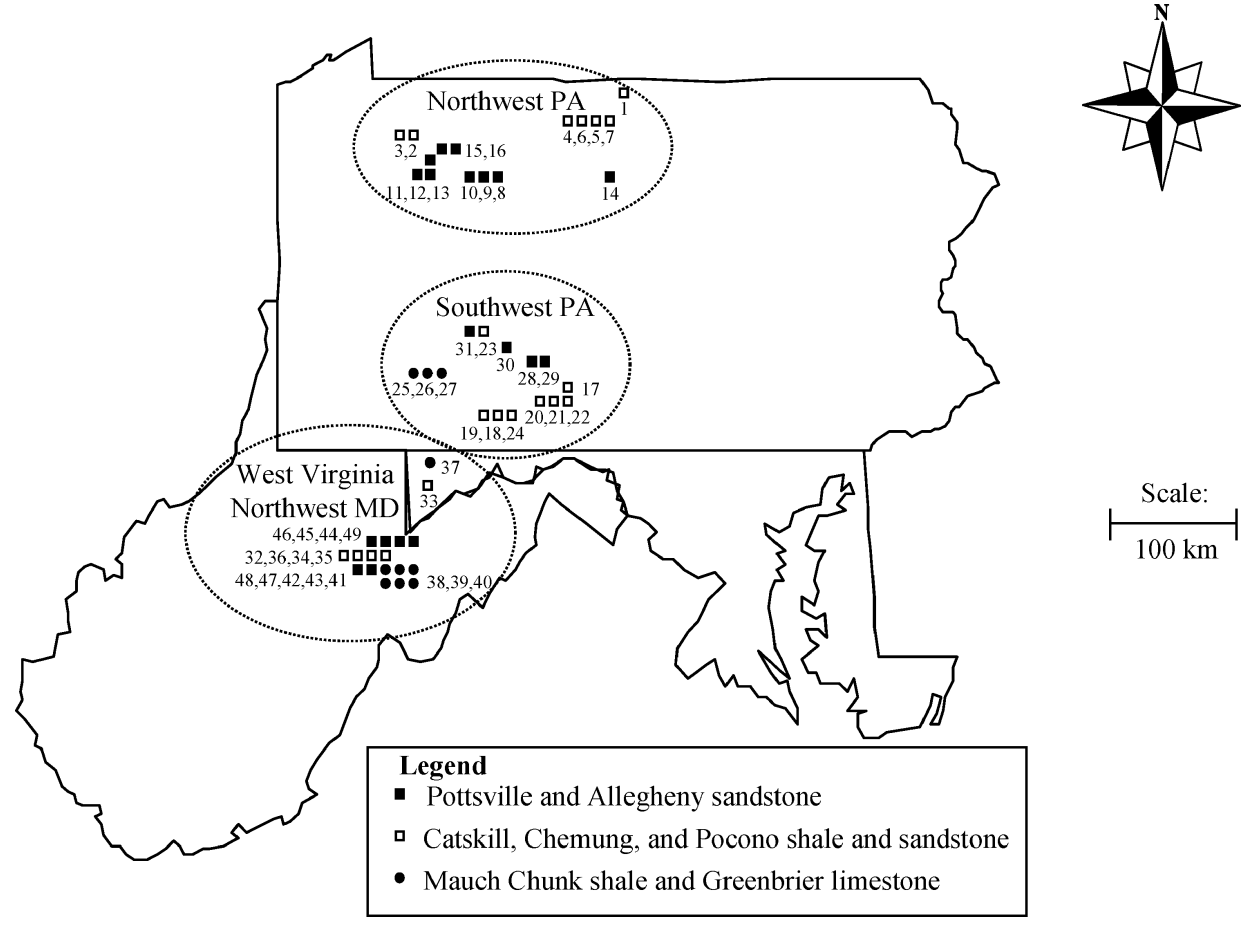

Figure 1. Locations and geology classification of the 49 study watersheds in the mid-Appalachian region of the United States. See Table I for watershed numbers and names.

intermediate, and high bedrock fertility and groundwater $\mathrm{pH}$ values (Ponce $e t$ al., 1979; Taylor et al., 1982, 1983; DeWalle et al., 1987). All of the study watersheds, except for East Branch Pine Creek, were located on unglaciated terrain.

The watersheds were classified further according to past land use or disturbance history (agriculture, burned, logged, and old-growth) (Table I). Agricultural watersheds were cultivated 60-90 years ago and were then left to regenerate to forestland. Past agriculture was documented using historical aerial photographs and present day clues (old fence posts, rock piles, foundations). Burned watersheds experienced severe fires 60-90 years ago caused by the abundant slash after the clearcutting of mid-Appalachian forests in the early 1900s. Current vegetation resulted from natural regeneration. Historical fire records and maps from the Allegheny National Forest, PA, Monongahela National Forest, WV, and Buchanan State Forest, PA were examined to locate severely burned areas. The logged watersheds were cut between 60 and 90 years ago, and did not experience any subsequent severe fires, based on fire records. Stand age inventories for the Monongahela National Forest, WV, Allegheny National Forest, PA, and Buchanan State Forest, PA were used to identify old-growth watersheds. Old-growth stands were defined as any stand not harvested within the past 150 years. Old-growth watersheds were located in 
TABLE I

Physical characteristics of the study watersheds

\begin{tabular}{|c|c|c|c|c|c|}
\hline Watershed & Region $^{\mathrm{a}}$ & Area $\left(\mathrm{km}^{2}\right)$ & Aspect & $\begin{array}{l}\text { Dominant bedrock } \\
\text { (geology category) }^{\mathrm{b}}\end{array}$ & Disturbance history \\
\hline E. Branch Pine Creek & NW PA & 0.860 & S & Huntley Mt. (CCP) & Agriculture \\
\hline Bimber Run & NW PA & 0.566 & SE & Shenango/Cuyahoga (CCP) & Agriculture \\
\hline Rt. Branch Camp Run & NW PA & 0.324 & $S$ & Shenango/Cuyahoga (CCP) & Agriculture \\
\hline Jones Run & NW PA & 0.702 & SSE & Catskill (CCP) & Agriculture \\
\hline Baker Hollow & NW PA & 3.124 & SSE & Catskill (CCP) & Logged \\
\hline Jacob Run & NW PA & 1.656 & ESE & Catskill (CCP) & Logged \\
\hline Sharpes Hollow & NW PA & 0.757 & SW & Huntley Mt. (CCP) & Logged \\
\hline Red Mill Run & NW PA & 3.370 & SE & Pottsville (PVA) & Burned \\
\hline Italian Shanty Run & NW PA & 2.673 & ENE & Pottsville (PVA) & Burned \\
\hline Crow Run & NW PA & 4.975 & SW & Pottsville (PVA) & Burned \\
\hline Little Salmon Creek & NW PA & 0.642 & $S$ & Pottsville (PVA) & Logged \\
\hline West Branch & NW PA & 1.474 & SE & Pottsville (PVA) & Logged \\
\hline The Branch & NW PA & 1.944 & SW & Pottsville (PVA) & Logged \\
\hline Beech Bottom Run & NW PA & 0.650 & NE & Pottsville (PVA) & Old-growth \\
\hline West Fork Run & NW PA & 3.699 & SW & Pottsville (PVA) & Old-growth \\
\hline East Fork Run & NW PA & 6.348 & SW & Pottsville (PVA) & Old-growth \\
\hline Sindeldecker Branch & SW PA & 2.976 & $\mathrm{E}$ & Catskill (CCP) & Burned \\
\hline Bear Gap Run & SW PA & 5.629 & SW & Tuscarora (CCP) & Burned \\
\hline Pigeon Roost Run & SW PA & 4.441 & $\mathrm{~S}$ & Tuscarora (CCP) & Burned \\
\hline Bowl Run & SW PA & 0.808 & SSE & Catskill (CCP) & Logged \\
\hline Betsey Gap Run & SW PA & 2.370 & ESE & Catskill (CCP) & Logged \\
\hline Little Point Run & SW PA & 1.662 & ESE & Catskill (CCP) & Logged \\
\hline Lick Run & SW PA & 7.708 & NE & Shenango/Oswayo (CCP) & Old-growth \\
\hline Sweet Root Gap & SW PA & 5.598 & ESE & Juniata (CCP) & Old-growth \\
\hline Little Run & SW PA & 0.639 & NNE & Mauch Chunk (MCG) & Agriculture \\
\hline Nedrow Run & SW PA & 0.990 & SE & Mauch Chunk (MCG) & Agriculture \\
\hline Roaring Run & SW PA & 0.542 & $\mathrm{~N}$ & Mauch Chunk (MCG) & Agriculture \\
\hline Gallitzen Run & SW PA & 0.639 & NE & Pottsville (PVA) & Logged \\
\hline Ashtola Run & SW PA & 1.371 & W & Pottsville (PVA) & Logged \\
\hline Deadlift Run & SW PA & 0.960 & SE & Allegheny (PVA) & Logged \\
\hline Tubmill Creek & SW PA & 14.005 & NNE & Allegheny (PVA) & Old-growth \\
\hline Clover Run & WV MD & 0.188 & SE & Chemung (CCP) & Agriculture \\
\hline Accident Run & WV MD & 0.639 & SE & Pocono (CCP) & Agriculture \\
\hline Fernow 4 & WV MD & 0.390 & NNW & Catskill (CCP) & Logged \\
\hline Fernow 10 & WV MD & 0.150 & $\mathrm{~N}$ & Catskill (CCP) & Logged \\
\hline Bear Run & WV MD & 1.753 & SE & Chemung (CCP) & Old-growth \\
\hline Little Bear Run & WV MD & 0.999 & NNE & Greenbrier (MCG) & Agriculture \\
\hline Freeland Run & WV MD & 1.284 & NNW & Mauch Chunk (MCG) & Logged \\
\hline East Freeland Run & WV MD & 0.402 & $\mathrm{~W}$ & Mauch Chunk (MCG) & Logged \\
\hline Salamander Run & WV MD & 1.063 & NW & Mauch Chunk (MCG) & Logged \\
\hline Karly Run & WV MD & 0.279 & SE & Mauch Chunk (MCG) & Logged \\
\hline West Three Spring & WV MD & 0.117 & $\mathrm{E}$ & Mauch Chunk (MCG) & Old-growth \\
\hline East Three Spring & WV MD & 0.115 & SE & Mauch Chunk (MCG) & Old-growth \\
\hline Engine Run & WV MD & 5.243 & SSE & Pottsville (PVA) & Burned \\
\hline Shays Run & WV MD & 6.030 & $\mathrm{~S}$ & Pottsville (PVA) & Burned \\
\hline Lindy Run & WV MD & 5.710 & SE & Pottsville (PVA) & Burned \\
\hline Otter Run & WV MD & 0.481 & $\mathrm{E}$ & Pottsville (PVA) & Logged \\
\hline Condon Run & WV MD & 3.472 & $\mathrm{E}$ & Pottsville (PVA) & Logged \\
\hline Red Brush Run & WV MD & 5.507 & NNW & Pottsville (PVA) & Logged \\
\hline
\end{tabular}

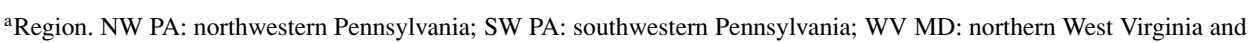
western Maryland.

${ }^{\mathrm{b}}$ Geology Category. CCP: Catskill, Chemung, and Pocono shale and sandstone; PVA: Pottsville and Allegheny sandstone; MCG: Mauch Chunk shale and Greenbrier limestone. 
the Tionesta Scenic and Natural Area, PA, the Sweet Root Natural Area, PA, the Rachelwood Preserve, PA, and adjacent to Otter Creek Wilderness, WV.

It was not possible to find each of the watershed types in each geology category. Therefore, an unbalanced experimental design resulted.

\subsection{FiELD MEASUREMENTS}

Stream water was grab sampled from all 49 watersheds at baseflow conditions from August 18 to 22, 1997 (summer) and March 11 to 14, 1998 (winter). Grab samples were analyzed for dissolved nitrate and ammonium at the Water Analysis Laboratory at The Pennsylvania State University using cadmium reduction and automated phenate methods, respectively (American Public Health Association, 1995). Stream $\mathrm{pH}$ and SEC were measured in the field using calibrated, portable meters (pHTestr 3 and TDSTestrby Oakton Inc., Singapore). Stream temperature was measured using a calibrated mercury thermometer.

Study watersheds were delineated on USGS 7.5-min quadrangle topographic maps. Catchment area and average basin slope were calculated using the delineated watershed boundaries. Watershed area was determined using a digital planimeter (Sokkia Corp., Overland Park, KS). Average basin slope was calculated using the Wentworth (1930) line-intersection method. Bedrock geology was determined with quadrangle geology maps (Reger, 1923, 1931; Maryland Geological Survey, 1953; Berg and Dodge, 1981). Basal area estimates of tree species were determined by point sampling with a 10 -factor wedge prism on 48 of 49 the study watersheds (Wenger, 1984). Red Brush Run in West Virginia was not sampled for tree basal area because the landowners did not grant access. Eight points were sampled on each watershed with 4 in the riparian zone and 4 on the mid-slope. Riparian zone points were spaced evenly along the length of the stream channel. Two mid-slope points were sampled on each of the two side slopes along the main channel.

Soil chemistry parameters were measured in August 1998 on a subset of 33 of the 49 watersheds. The 33 watersheds were chosen to obtain at least two experimental units (catchments) within each land use type (burned, agriculture, logged, old-growth) in each of the three regions. On each watershed, three 16-m sampling transects were located by watershed position and elevation. Transect 1 was located near the watershed mouth (stream water sampling point) at a low elevation. Transect 2 was located near the middle of the watershed at a mid-slope elevation. Transect 3 was located in the headwaters of the watershed at a ridge top elevation. Nine soil sampling points were spaced at $2 \mathrm{~m}$ intervals along each sampling transect for a total of 27 soil sampling points per watershed. At each soil sampling point, the entire organic horizon was sampled with a sharpshooter shovel and the top $10 \mathrm{~cm}$ of mineral soil was sampled with a $10 \mathrm{~cm}$ diameter soil corer. Organic and mineral soil samples were transported to The Pennsylvania State University, Agricultural Analytical Laboratory for analyses. Exchangeable $\mathrm{Ca}, \mathrm{Mg}$, and $\mathrm{K}$ and labile, mineralized $\mathrm{P}$ 
were determined with the Mehlich 3 method (Wolfe and Beegle, 1995). Exchangeable acidity was extracted and measured with the Shoemaker, McLean, and Pratt (SMP) buffer method (Sims and Eckert, 1995). Soil pH was measured in a slurry ( $5 \mathrm{~g}$ soil: $5 \mathrm{ml}$ distilled water) using an electronic $\mathrm{pH}$ meter (Sims and Eckert, 1995). Effective cation exchange capacity (CEC) was calculated by summing the exchangeable $\mathrm{Ca}, \mathrm{Mg}, \mathrm{K}$, and acidity (Ross, 1995). Organic and mineral soil were analyzed for total $\mathrm{C}$ and $\mathrm{N}$ at the USDA Forest Service's Timber and Watershed Laboratory in Parsons, WV using an organic elemental analyzer (Carlo Erba NA 1500 CNS Analyzer, Valencia, CA) (Baccanti et al., 1993).

\subsection{STATISTICAL METHODS}

Four data sets were analyzed statistically: stream chemistry of 49 watersheds, soil chemistry of 33 watersheds, physiographic parameters of 49 watersheds, and vegetation inventory of 48 watersheds. The SAS Institute Inc. statistical package, Version 7 for Windows (1998), was used to analyze the data sets. Each data set was analyzed to determine if the error terms were normally distributed and homogeneous (assumptions underlying ANOVA). Normal probability plots and Shapiro-Wilk test statistics (SAS Institute Inc., 1985) confirmed that all the data sets were normally distributed. Bartlett's tests (SAS Institute Inc., 1985) showed error variances for the ANOVA models to be relatively homogeneous. Given the normal distribution of data and the homogeneity of error variance, no data transformations were required for subsequent analysis of variance tests (ANOVA).

ANOVA models for stream chemistry, soil chemistry, physiographic, and vegetation inventory data sets included the following terms: (1) geographic region (NW PA, SW PA, and MD WV), (2) geology category (PVA, CCP, and MCG), and (3) land use (burned, agriculture, logged, and old-growth). Tukey's studentized range test (HSD) was added to each model to test for significant differences among the single factors: region, geology category, and land use for each dependent variable. The stream chemistry ANOVA model was run for summer and winter separately. Pearson correlation tests were run among the stream chemistry, soil chemistry, physiographic, and vegetation inventory data sets. A maximum $R^{2}$ improvement stepwise regression model (SAS Institute Inc., 1985) also was constructed to determine the factors that best predicted stream nitrate concentrations. The three geology and four land use categories were included in the stepwise regression model as dummy variables. All tests of significance were made at the $\alpha=0.05$ confidence level.

\section{Results and Discussion}

Stream ammonium-N concentrations were at or near the detection limit $(0.005 \mathrm{mg}$ $\mathrm{L}^{-1} \mathrm{NH}_{4}^{+}-\mathrm{N}$ ) in most of the 49 study watersheds, but as expected, nitrate concentrations varied widely $\left(<0.005-1.702 \mathrm{mg} \mathrm{L}^{-1}\right.$ nitrate-N). However, stream nitrate 
concentrations did not vary significantly among geographic regions (NW PA, SW PA, and WV MD) (Figure 1).

An examination of stream nitrate change in rank order over time can help assess whether a two-time baseflow survey serves as an adequate representation of stream nitrate concentrations. The median change in rank order for the 47 sampled watersheds between August 1997 and March 1998 was 6 with a 95\% confidence interval of \pm 2 , using a non-parametric sign test with an S table (Noether, 1991). Thus, the 47 watersheds exhibited little change in rank, which indicates that a two-time survey can serve as an adequate index to stream nitrate concentrations. Also, Edwards et al. (2004) showed that relatively low intensity stream sampling (quarterly) in WV could be used to predict actual stream nitrate loads from forested watersheds as accurately as more intensive sampling (weekly) because of the small fluctuation in nitrate concentrations over flow and time.

Two of the 49 watersheds included in the baseflow surveys were intensively monitored experimental watersheds in the Fernow Experimental Forest, Fernow 4 and Fernow 10. Our summer nitrate-N concentrations from Fernow 4 and Fernow 10 (0.770 and $0.394 \mathrm{mg} \mathrm{L}^{-1}$, respectively) and winter concentrations ( 0.731 and $0.038 \mathrm{mg} \mathrm{L}^{-1}$, respectively) fell well within the range of weekly nitrate-N concentrations from water years 1996 to 1999 and closely approximated the mean nitrate-N concentration from these water years (Table II). These results provide additional

TABLE II

\begin{tabular}{|c|c|c|c|c|}
\hline Water year & Mean & S.D. & Minimum & Maximum \\
\hline \multicolumn{5}{|c|}{ WS4 growing season $\mathrm{NO}_{3}-\mathrm{N}$} \\
\hline 1997 & 0.653 & 0.016 & 0.51 & 0.86 \\
\hline 1998 & 0.713 & 0.026 & 0.50 & 1.00 \\
\hline 1996-1999 & 0.685 & 0.015 & 0.50 & 1.48 \\
\hline \multicolumn{5}{|c|}{ WS4 dormant season $\mathrm{NO}_{3}-\mathrm{N}$} \\
\hline 1997 & 0.765 & 0.009 & 0.69 & 0.87 \\
\hline 1998 & 0.904 & 0.023 & 0.67 & 1.09 \\
\hline 1996-1999 & 0.787 & 0.012 & 0.60 & 1.09 \\
\hline \multicolumn{5}{|c|}{ WS10 growing season $\mathrm{NO}_{3}-\mathrm{N}$} \\
\hline 1997 & 0.195 & 0.017 & 0.11 & 0.29 \\
\hline 1998 & 0.311 & 0.052 & 0.15 & 0.62 \\
\hline 1996-1999 & 0.224 & 0.021 & 0 & 0.68 \\
\hline \multicolumn{5}{|c|}{ WS10 dormant season $\mathrm{NO}_{3}-\mathrm{N}$} \\
\hline 1997 & 0.121 & 0.016 & 0 & 0.19 \\
\hline 1998 & 0.273 & 0.073 & 0.11 & 1.07 \\
\hline 1996-1999 & 0.188 & 0.028 & 0 & 1.07 \\
\hline
\end{tabular}


support for the adequacy of two-time baseflow surveys to characterize the stream nitrate concentrations.

\subsection{EXPLAINING STREAM NITRATE VARIATION}

\subsubsection{Geology}

The significant variability in stream nitrate concentrations among the study watersheds was related to differences in bedrock geology (Table III). The MCG, CCP, and PVA bedrock watersheds had the highest, intermediate, and lowest mean summer and winter stream nitrate- $\mathrm{N}$ concentrations, respectively (Figure 2). Ponce et al. (1979) found that stream nitrate varied by bedrock type in the Little Black Fork watershed in West Virginia. Stream water associated with Greenbrier limestone had the highest mean nitrate-N concentration $\left(1.31 \mathrm{mg} \mathrm{L}^{-1}\right)$, and those

TABLE III

Mean stream chemistry, soil chemistry, and physiographic parameter values for the three geology categories

\begin{tabular}{lccc}
\hline Parameter & PVA & CCP & MCG \\
\hline Summer stream $\mathrm{NO}_{3}-\mathrm{N}\left(\mathrm{mg} \mathrm{L}^{-1}\right)$ & $0.162 \mathrm{a}^{*}$ & $0.424 \mathrm{~b}$ & $0.750 \mathrm{c}$ \\
Winter stream $\mathrm{NO}_{3}-\mathrm{N}\left(\mathrm{mg} \mathrm{L}^{-1}\right)$ & $0.174 \mathrm{a}$ & $0.398 \mathrm{~b}$ & $0.940 \mathrm{c}$ \\
Summer stream pH & $5.10 \mathrm{a}$ & $6.59 \mathrm{~b}$ & $6.96 \mathrm{~b}$ \\
Winter stream pH & $5.03 \mathrm{a}$ & $6.23 \mathrm{~b}$ & $6.56 \mathrm{~b}$ \\
Summer stream SEC $\left(\mu \mathrm{S} \mathrm{cm}^{-1}\right)$ & $36.1 \mathrm{a}$ & $36.0 \mathrm{a}$ & $46.5 \mathrm{a}$ \\
Winter stream SEC $\left(\mu \mathrm{S} \mathrm{cm}^{-1}\right)$ & $26.8 \mathrm{a}$ & $28.5 \mathrm{a}$ & $32.0 \mathrm{a}$ \\
$\mathrm{C}$ in organic soil $(\%)$ & $18.980 \mathrm{a}$ & $14.055 \mathrm{~b}$ & $16.185 \mathrm{ab}$ \\
$\mathrm{C}$ in mineral soil $(\%)$ & $4.067 \mathrm{a}$ & $3.979 \mathrm{a}$ & $5.042 \mathrm{~b}$ \\
$\mathrm{~N}$ in organic soil $(\%)$ & $0.895 \mathrm{a}$ & $0.733 \mathrm{~b}$ & $0.917 \mathrm{a}$ \\
$\mathrm{N}$ in mineral soil $(\%)$ & $0.262 \mathrm{a}$ & $0.265 \mathrm{a}$ & $0.382 \mathrm{~b}$ \\
$\mathrm{C}: \mathrm{N}$ ratio of organic soil & $20.720 \mathrm{a}$ & $19.013 \mathrm{~b}$ & $16.918 \mathrm{c}$ \\
$\mathrm{C}: \mathrm{N}$ ratio of mineral soil & $15.603 \mathrm{a}$ & $15.062 \mathrm{a}$ & $13.394 \mathrm{~b}$ \\
Organic soil P (meq. $\left.\mathrm{kg}^{-1}\right)$ & $0.0036 \mathrm{a}$ & $0.0062 \mathrm{~b}$ & $0.0046 \mathrm{ab}$ \\
Mineral soil P (meq. $\left.\mathrm{kg}^{-1}\right)$ & $0.0026 \mathrm{a}$ & $0.0041 \mathrm{a}$ & $0.0029 \mathrm{a}$ \\
Organic soil Ca (meq. $\left.\mathrm{kg}^{-1}\right)$ & $0.124 \mathrm{a}$ & $0.168 \mathrm{~b}$ & $0.226 \mathrm{c}$ \\
Mineral soil Ca (meq. kg $\left.\mathrm{kg}^{-1}\right)$ & $0.072 \mathrm{a}$ & $0.080 \mathrm{ab}$ & $0.105 \mathrm{~b}$ \\
Organic soil pH & $3.59 \mathrm{a}$ & $3.97 \mathrm{~b}$ & $4.06 \mathrm{~b}$ \\
Mineral soil pH & $3.73 \mathrm{a}$ & $4.01 \mathrm{~b}$ & $4.01 \mathrm{~b}$ \\
Average basin slope $\left({ }^{\circ}\right)$ & $5.955 \mathrm{a}$ & $12.998 \mathrm{~b}$ & $17.209 \mathrm{~b}$ \\
Area (km $\left.{ }^{2}\right)$ & $3.642 \mathrm{a}$ & $2.115 \mathrm{ab}$ & $0.643 \mathrm{~b}$ \\
\hline
\end{tabular}

*Parameter means with different letters across the three geology categories are significantly different at $\alpha=0.05$ using Tukey's HSD mean separation procedure. 


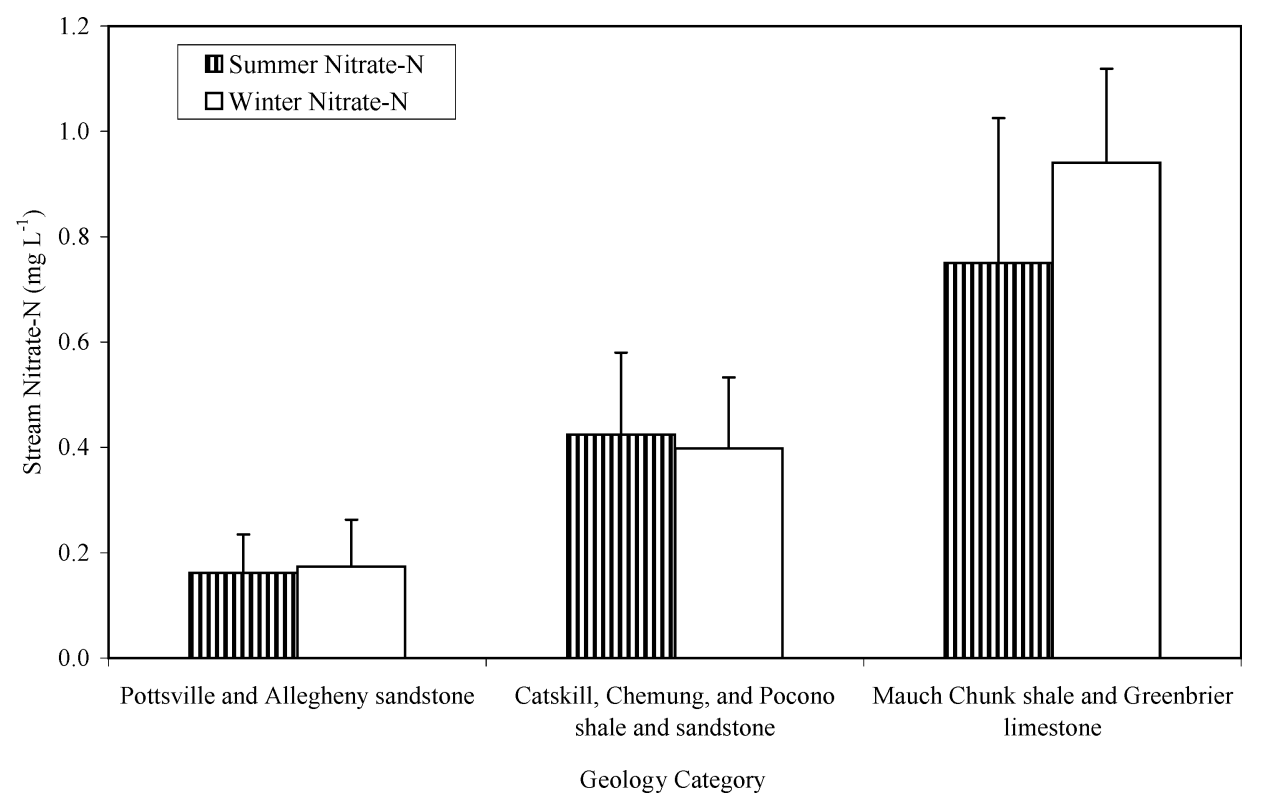

Figure 2. Mean summer and winter stream nitrate-N concentrations for the three geology categories.

associated with Mauch Chunk shale also yielded water relatively enriched in nitrate$\mathrm{N}\left(1.02 \mathrm{mg} \mathrm{L}^{-1}\right)$. The Catskill shale and sandstone in Little Black Fork watershed yielded water with a lower mean nitrate- $\mathrm{N}$ concentration $\left(0.69 \mathrm{mg} \mathrm{L}^{-1}\right)$. These findings and concentrations are consistent with our data for MCG and CCP geologies. By contrast, Ponce et al. (1979) found that stream water from Pottsville sandstone yielded stream water with a mean nitrate- $\mathrm{N}$ concentration of $1.04 \mathrm{mg} \mathrm{L}^{-1}$, which was significantly higher than the mean nitrate-N concentrations we found $(0.162$ and $0.174 \mathrm{mg} \mathrm{L}^{-1}$ ). The mean nitrate-N concentration from Pottsville sandstone reported by Ponce et al. (1979) (1.04 $\left.\mathrm{mg} \mathrm{L}^{-1}\right)$ was similar to the nitrate-N concentration from Mauch Chunk shale $\left(1.02 \mathrm{mg} \mathrm{L}^{-1}\right)$ in our study. Mauch Chunk shale may influence water thought to originate from Pottsville sandstone because it is found beneath the Pottsville layer. At Laurel Hill, PA, Goyne (1998) showed that the mean soil solution nitrate-N concentration in A-horizons derived from Mauch Chunk shale $\left(0.511 \mathrm{mg} \mathrm{L}^{-1}\right)$ was significantly greater than in A-horizons derived from Pottsville sandstone $\left(0.167 \mathrm{mg} \mathrm{L}^{-1}\right)$. This relationship follows the stream nitrate differences we observed between MCG and PVA watersheds.

Other studies did not show a relationship between stream nitrate and bedrock type (Silsbee and Larson, 1982; Johnson and Reynolds, 1977); however, neither of these two surveys included a geologic strata that produced relatively high $\mathrm{pH}$ waters like MCG. Silsbee and Larson (1982) analyzed stream water quality in two dominant geology types in the Great Smokey Mountains National Park. Nitrate-N was only slightly higher in waters from the Anakeesta formation $\left(0.856 \mathrm{mg} \mathrm{L}^{-1}\right)$, 
which is composed of slate, phyllite and/or schist with significant amounts of pyrite, compared to the Great Smokey Group $\left(0.673 \mathrm{mg} \mathrm{L}^{-1}\right)$, which is composed of thickbedded sandstone containing quartz and feldspars. Johnson and Reynolds (1977) found similar stream nitrate concentrations in stream water from plutonic bedrock (quartz, granite) and from metamorphic and sedimentary bedrock (schist and slate).

In forested watersheds in the western United States, Dahlgren (1994) and Holloway et al. (1998) found that muscovite and sericite minerals in bedrock provided a significant source of nitrogen as interlayer ammonium. Although we did not measure the nitrogen content of bedrock in our study, geologic literature does not indicate that any of our bedrock types contain significant quantities of interlayer ammonium or other nitrogen forms. Consequently, bedrock geology must control stream water nitrate by an indirect mechanism in which bedrock determines soil fertility, which influences soil nitrogen cycling and nitrate leaching.

\subsubsection{Past Land Disturbances}

Past land disturbances did not explain a significant amount of nitrate variation during winter. During summer, watersheds with a past agricultural history yielded significantly greater mean nitrate- $\mathrm{N}$ concentrations $\left(0.812 \mathrm{mg} \mathrm{L}^{-1}\right)$ compared to the three other land use histories (burned $=0.091 \mathrm{mg} \mathrm{L}^{-1}$, logged $=0.308 \mathrm{mg} \mathrm{L}^{-1}$, oldgrowth $=0.423 \mathrm{mg} \mathrm{L}^{-1}$ ). However, agricultural watersheds occurred only within the two most fertile geology categories (CCP and MCG). Among the agricultural watersheds, the MCG geology watersheds had a significantly higher mean nitrate-N concentration $\left(1.136 \mathrm{mg} \mathrm{L}^{-1}\right)$ than the CCP geology watersheds $\left(0.596 \mathrm{mg} \mathrm{L}^{-1}\right)$ in a paired $t$-test. As a result, past land use differences did not appear to account for any of the stream nitrate variation beyond that which was already explained by geology.

\subsubsection{Physiographic Parameters}

Stream nitrate did not differ significantly by watershed aspect, the physiographic parameter we predicted would most likely affect stream nitrate concentrations due to its microclimatic effects on soil temperature. However, winter stream nitrate was correlated positively with average basin slope $(r=0.417, p=0.003)$ and negatively with watershed area $(r=-0.310, p=0.030)$. Summer stream nitrate also was correlated negatively with watershed area $(r=-0.294, p=0.042)$. In the ANOVA model, average basin slope varied by geology category in the same manner as stream nitrate-N (Table III). The PVA geology watersheds were located primarily on the top of slopes on broad, flat plateaus, which resulted in the significantly lower average basin slope for this geology type. The significant negative correlation between watershed area and stream nitrate was also likely a function of geology. The PVA bedrock watersheds were larger in area, due to these expansive plateaus, suggesting that the correlations between average basin slope, watershed area and stream nitrate may be a function of geologic differences that affected landform, rather than direct relationships. 


\subsubsection{Vegetation}

One would expect vegetation to affect nitrate leaching primarily during the growing season. Summer stream nitrate concentrations were correlated positively with the mean watershed (riparian zone and mid-slope) basal area of sugar maple (Acer saccharum Marsh.), white ash (Fraxinus americana L.), and black locust (Robinia pseudoacacia L.) and negatively correlated with the mean watershed basal area of eastern hemlock (Tsuga canadensis L.) (Table IV). Riparian zone basal areas of each of the four species were correlated better with summer stream nitrate concentrations than mid-slope basal areas. This was likely due to the deeper and more fertile riparian soils having a greater influence on nitrogen cycling and transport compared to the mid-slope soils.

This study did not yield a significant correlation between red oak (Quercus rubra L.) and stream nitrate concentrations (Table IV), in contrast to studies by Lovett et al. (2000) in the Catskill Mountains of New York and Lewis and Likens (2000) in the Allegheny National Forest in northwestern PA. Lovett et al. (2000) analyzed nitrate concentrations from 39 streams and found the three lowest were from watersheds dominated by red oak; the five highest were from watersheds with no oaks. Lovett et al.'s (2000) study area was glaciated, resulting in relatively homogeneous soil fertility characteristics among the study watersheds. Thus, tree species composition will likely have a greater influence on nitrate leaching from these watersheds compared to our unglaciated study region. Lewis and Likens (2000) finding of low stream nitrate concentrations in watersheds containing red oak may be attributed to the relative abundance of acidic bedrock (Pottsville) in those Allegheny National Forest watersheds.

\section{TABLE IV}

Pearson correlation coefficients between summer stream nitrate concentrations and mean watershed basal area of overstory species on 48 study watersheds

\begin{tabular}{lcc}
\hline & \multicolumn{2}{c}{ Summer stream nitrate concentrations } \\
\cline { 2 - 3 } Overstory species (basal area) & Correlation coefficient $(r)$ & $p$ value \\
\hline Sugar maple & 0.411 & 0.004 \\
Black locust & 0.410 & 0.004 \\
White ash & 0.305 & 0.037 \\
Eastern hemlock & -0.282 & 0.055 \\
Red oak & 0.148 & 0.319 \\
Birch & -0.137 & 0.358 \\
American beech & -0.104 & 0.486 \\
Red maple & -0.096 & 0.521 \\
Black cherry & -0.029 & 0.845 \\
Yellow poplar & -0.028 & 0.854 \\
\hline
\end{tabular}


Of the four species correlated with summer stream nitrate concentrations, sugar maple, white ash, and eastern hemlock each covaried with bedrock geology. The MCG, CCP, PVA geology watersheds had the highest, intermediate, and lowest mean watershed basal areas of both sugar maple and white ash, respectively. Sugar maple and white ash are usually more prevalent on relatively fertile sites (MCG) (Godman et al., 1990; Schlesinger, 1990). Watersheds containing PVA geology had significantly greater mean basal area of eastern hemlock compared to watersheds with other geology types. Eastern hemlock is associated most commonly with acidic soils (Godman and Lancaster, 1990).

Of the tree species correlated with stream nitrate, only black locust occurrence was not related to bedrock geology. Black locust is one of the few eastern United States forest species that support symbiotic nitrogen fixation. Danso et al. (1995) estimated that field-grown black locust in Austria fixed $110 \mathrm{~kg} \mathrm{~N} \mathrm{ha}^{-1}$ per year. Nitrogen fixation rates in eastern United States forests may be even greater, since the growing season in the eastern United States is approximately 1-2 months longer than in Austria. In the southern Appalachians, Montagnini et al. (1986) found soils beneath black locust had greater mineralization and nitrification rates than surrounding soils under different vegetative cover, because of higher soil $\mathrm{N}$ pools. This can lead to greater soil solution nitrate concentrations underneath black locust stands (Montagnini et al., 1986, 1991), and, as a result, higher stream nitrate concentrations. Therefore, the relative abundance of black locust on the study watersheds may help explain some of the additional variation in stream nitrate concentrations beyond that attributable to geology.

Black locust was found on 10 of the 48 watersheds inventoried for vegetation, but was a relatively minor stand component $(2.9 \%$ of the total mean watershed basal area) of those 10 watersheds. While we did not measure soil or solution chemistry beneath black locust stands or individual trees, the significant correlation between the mean watershed basal area of black locust and stream nitrate concentrations indicates that black locust may have a significant secondary effect on stream nitrate at the watershed scale. Relatively high $\mathrm{N}$-fixation rates by black locust (Danso et al., 1995) may mean that even isolated stands of black locust can significantly increase nitrate leaching to streams. Stednick and Kern (1992) found that nitrate concentrations in stream water were greatest when another nitrogen-fixer, red alder (Alnus rubra Bong.) was abundant in the riparian zones that contributed stream water, even if alder did not cover a substantial portion of the watershed.

\subsubsection{Soil Chemistry}

Summer stream nitrate concentrations were correlated significantly with organic and mineral soil exchangeable calcium $(r=0.438, p=0.011), \mathrm{pH}(r=0.374$, $p=0.032)$, and $\mathrm{C}: \mathrm{N}$ ratios $(r=-0.401, p=0.021)$ on 33 watersheds. Winter stream nitrate concentrations were correlated with organic and mineral soil $\% \mathrm{~N}$ $(r=0.397, p=0.022)$ and $\mathrm{C}: \mathrm{N}$ ratios $(r=-0.398, p=0.022)$. All of these soil chemistry parameters affect $\mathrm{N}$ mineralization and nitrification rates, and thus, 
nitrate leaching to streams (Norris et al., 1991; Paul and Clark, 1996; Williard et al., 1997; Gundersen et al., 1998). Dise et al. (1998) and Gundersen et al. (1998) found that organic soil C:N ratios were correlated negatively with stream nitrate levels across a large number (111 and 33, respectively) of European forested watersheds. Lovett et al. (2002) showed also that organic soil C:N ratios were a significant predictor of stream nitrate concentrations from 39 forested watersheds in the Catskill region of New York, United States. High soil C:N ratios result in strong heterotrophic soil microbe demand for $\mathrm{N}$, leaving less $\mathrm{N}$ available for nitrifying microbes and subsequent nitrate leaching (Riha et al., 1986; Schimel and Firestone, 1989). Thus, at $\mathrm{C}: \mathrm{N}$ ratios $>30$, net immobilization of nitrogen usually occurs, while $\mathrm{C}: \mathrm{N}$ ratios $<20$ generally result in net mineralization (Alexander, 1977). All the study watersheds had organic and mineral soil C:N ratios $<30$, with most $<20$. The positive correlation between soil $\mathrm{pH}$ and stream nitrate was expected, given that decreases in soil $\mathrm{pH}$ have been shown to depress $\mathrm{N}$ mineralization and nitrification rates, especially at $\mathrm{pH}$ levels below 5.0 (Alexander, 1977; Paul and Clark, 1996).

Exchangeable calcium levels may affect inorganic nitrogen cycling rates beyond indirectly affecting acidity. Calcium is an essential element utilized in the structure and regulatory functions of bacterial cells (Norris et al., 1991; Smith, 1995). Norris et al. (1991) reported that low calcium levels can limit the growth rates of several types of bacteria, including species of Azotobacter, the primary group of $\mathrm{N}$-fixing bacteria. Thus, low calcium concentrations could limit $\mathrm{N}$-fixation rates, reducing available $\mathrm{N}$ to nitrifying microbes. Low calcium also may directly limit the growth of Nitrosomonas and Nitrobacter bacteria and/or fungi responsible for nitrification.

Organic and mineral soil exchangeable calcium, $\mathrm{pH}, \% \mathrm{~N}$, and $\mathrm{C}: \mathrm{N}$ ratios varied by geology category, in the same manner as stream nitrate- $\mathrm{N}$ concentrations (Table III). The PVA, CCP, and MCG geology categories generally had the lowest, intermediate, and highest $\mathrm{Ca}, \mathrm{pH}$, and $\% \mathrm{~N}$, respectively in both organic and mineral soil. The only exception was that PVA geology watersheds had significantly higher $\% \mathrm{~N}$ in the organic soil than CCP geology watersheds (Table III), probably due to lower mineralization rates of $\mathrm{N}$ in the more acidic soils derived from the PVA bedrock. PVA, CCP, and MCG watersheds had the highest, intermediate, and lowest organic and mineral soil $\mathrm{C}: \mathrm{N}$ ratios, respectively. Lower $\mathrm{C}: \mathrm{N}$ ratios in the least acidic geology types (MCG) likely are due to more rapid decomposition and cycling of fresh litter.

\subsection{FERNOW 4 WATERSHED AND NITROGEN SATURATION}

Our survey of 49 streams included Fernow 4, a watershed that has exported relatively high amounts of nitrate for the past two decades (Adams et al., 1993). On Fernow 4, stream nitrate-N outputs $\left(5.1 \mathrm{~kg} \mathrm{ha}^{-1}\right.$ per year) are nearly equal to nitrate-N bulk deposition inputs $\left(5.0 \mathrm{~kg} \mathrm{ha}^{-1}\right.$ per year) and the stream nitrate outputs show little seasonal variation (Adams et al., 1993; P. Edwards, personal 
communication), which are both indicators of nitrogen saturation (Peterjohn et al., 1996; Gilliam et al., 1996). Nitrogen saturation can be defined generally as a forest ecosystem condition where nitrogen is supplied in excess of microbial and vegetative demand (Agren and Bosatta, 1988; Aber et al., 1989, 1998). In fact, Fernow 4 has been cited as the best example of a stage 2 nitrogen saturated watershed in the northeastern United States, since the watershed exhibits elevated year round nitrate concentrations (Stoddard, 1994; Peterjohn et al., 1996; Fenn et al., 1998).

Among CCP watersheds, Fernow 4 was at the high end of the distribution of stream nitrate concentrations. In the winter and summer baseflow surveys, Fernow 4 had the 11th and seventh highest stream nitrate- $\mathrm{N}$ concentration $(0.731$ and $0.770 \mathrm{mg} \mathrm{L}^{-1}$, respectively) of the 49 and 48 watersheds sampled. Given the number of watersheds that had greater stream nitrate concentrations than Fernow 4, nitrogen saturation may be more prevalent in the mid-Appalachian region than previously thought. Williard et al. (2003) conducted more localized summer and fall stream nitrate surveys of forested watersheds within $10 \mathrm{~km}$ of Fernow 4 and found that nearly half of the 27 streams sampled had greater stream nitrate concentrations than Fernow 4, suggesting that nitrogen saturation is a relatively common condition within that locality.

\subsection{Predicting StREAM NitRATE CONCENTRATions}

Maximum $R^{2}$ stepwise regression models containing geology dummy variables $(\mathrm{PVA}=1, \mathrm{CCP}=2, \mathrm{MCG}=3$ ), land use dummy variables (burned $=1$, agricultural $=2$, logged $=3$, old-growth $=4$ ), organic and mineral soil chemistry, vegetation, and physiographic parameters were constructed to determine which factors best predicted winter and summer stream nitrate concentrations. Geology categories were arranged from high to low acidity. Land uses were arranged from most severe to least severe historical disturbance. Geology dummy variables were the first parameters to enter the stepwise regressions of winter and summer stream nitrate. The geology dummy variables alone explained $49 \%$ of the variation in winter stream nitrate-N concentrations (Figure 3). Excluding parameters correlated with geology (soil chemistry, physiographic parameters, and some vegetation types), no other variables were significant additions to the regression model.

Three watersheds (East Fork, West Fork, and Accident Run) in Figure 3 may be termed outlier points, since their nitrate- $\mathrm{N}$ concentrations were greater than two standard deviations from the mean of their geology category. These watersheds were on the high end of the stream nitrate distributions within the PVA and CCP geology categories. Accident Run, in the CCP geology category, was a past agricultural watershed, indicating that past farming may affect nitrate leaching on individual watershed basis. The two outlier watersheds in the PVA geology category were both old-growth watersheds, suggesting that stand age also may be important in explaining stream nitrate concentrations from individual watersheds. 


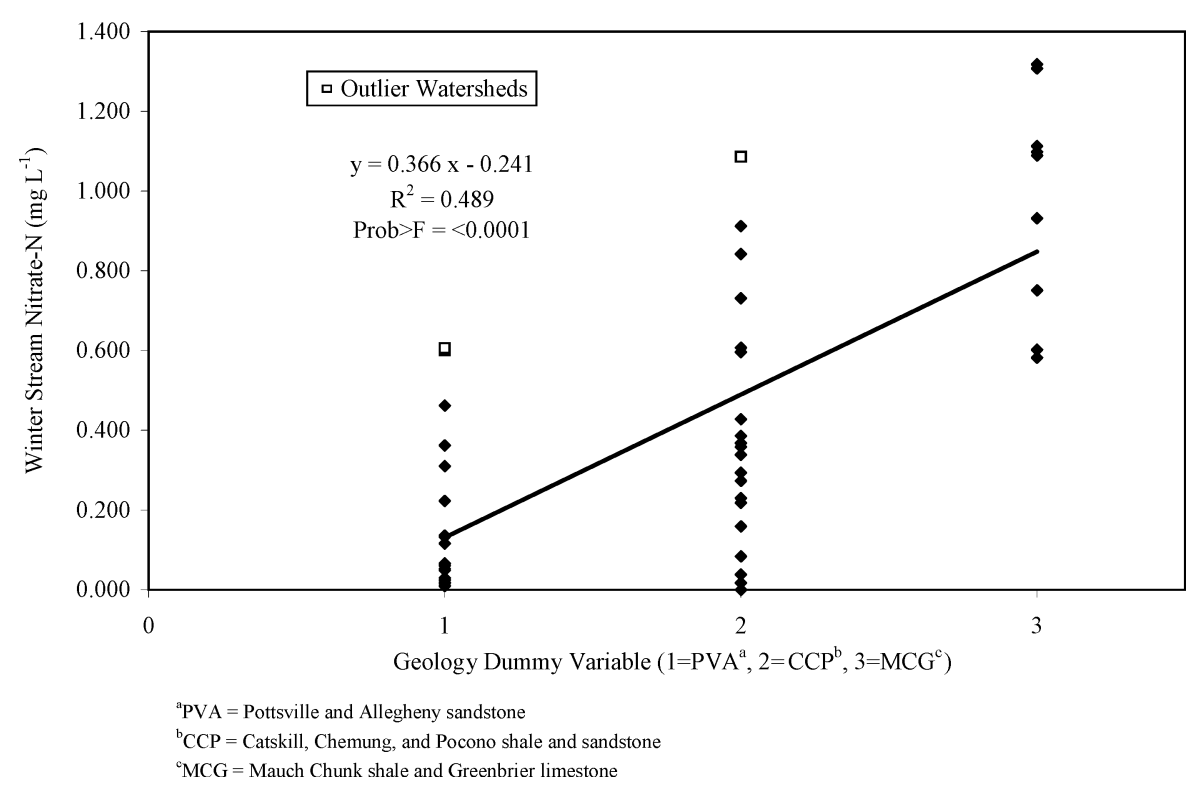

Figure 3. Winter stream nitrate-N concentrations versus the three geology categories.

Also, the three outlier watersheds were all south-facing. South-facing watersheds receive more solar radiation, resulting in higher soil temperatures that may stimulate N-mineralization and nitrification rates, and consequently, nitrate leaching. Thus, high nitrate leaching rates on the outlier watersheds may be due partially to watershed aspect. Average basin slope and dominant overstory vegetation did not show any consistent relationships among the three outlier watersheds.

One could argue that soil chemistry differences are a more direct cause of stream nitrate variation than geology. Parameters such as $\mathrm{C}: \mathrm{N}$ ratios and soil $\mathrm{pH}$ have been shown to directly affect the nitrate production in the soil and, thus, are more responsible for differences in nitrate leaching to streams. Soil $\mathrm{pH}$ was not a significant parameter in any winter regression models. When only organic and mineral soil chemistry parameters were included in a stepwise regression model for winter stream nitrate, $\mathrm{C}: \mathrm{N}$ ratios explained the most variation $(16 \%)$ in stream nitrate. The best two-parameter model included $\mathrm{C}: \mathrm{N}$ ratios and $\% \mathrm{~N}$, which together explained $29 \%$ of the variation in winter stream nitrate. Neither of these soil chemistry based models approached the predictive power of the geology model for winter stream nitrate $(49 \%)$. This may be a function of geology being more accurately represented within the large regional scope of the study, compared to soil chemistry, which varies significantly at the micro-scale.

Summer stream nitrate predictions yielded similar results. In a stepwise regression, geology explained the most variation (32\%) in stream nitrate. Basal area of black locust joined geology in a significant two-variable model, explaining $40 \%$ of the variation in summer stream nitrate (Figure 4). Black locust, a nitrogen fixing 


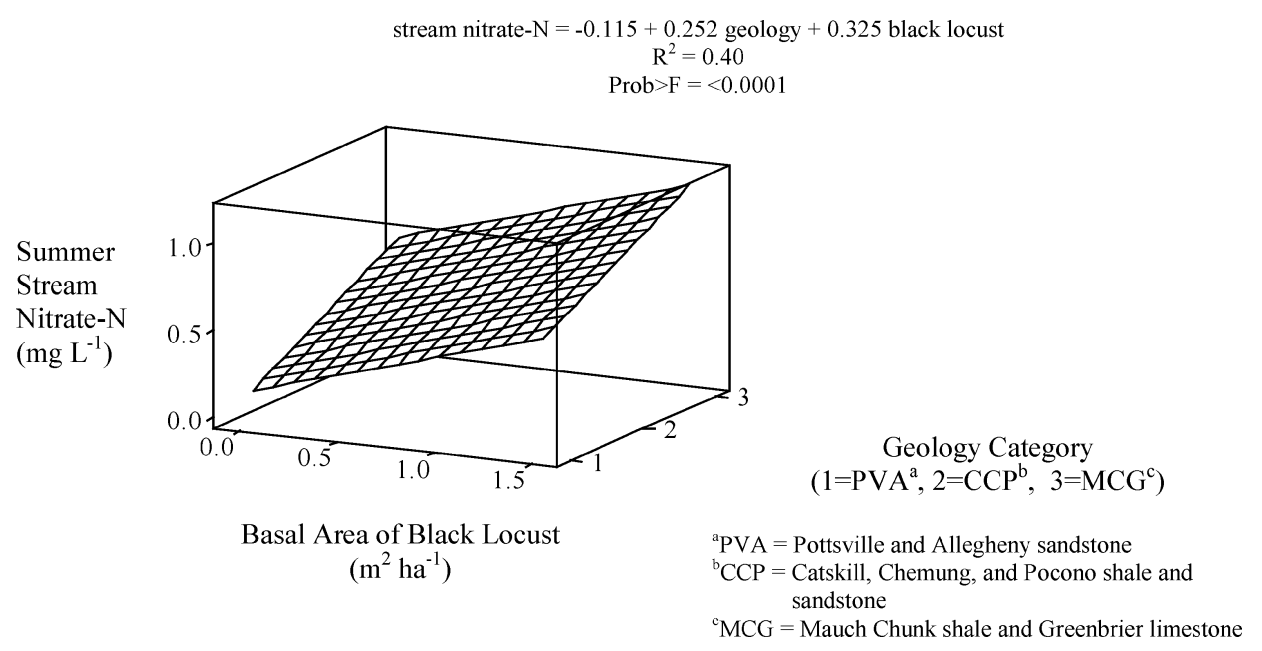

Figure 4. Summer stream nitrate-N concentrations versus the three geology categories and the basal area of black locust.

species, had an additional effect on nitrate leaching beyond the effects of geology, since it was not related to differences in geology.

Organic and mineral soil chemistry parameters did not predict summer stream nitrate concentrations as well as geology. Of the soil chemistry variables, exchangeable soil calcium was the single soil factor that explained the most variation (19\%) in summer stream nitrate. The best two-parameter soil chemistry model included C:N ratios and mineralized phosphorus, which together explained $27 \%$ of the variation.

There are several factors that were not assessed in this study that could potentially account for some of the unexplained variation in stream nitrate concentrations including differences in denitrification, in-stream $\mathrm{N}$ processing, and insect defoliation among the study watersheds. Riparian denitrification rates can be highly variable within a watershed and among watersheds, given differences groundwater flow paths and labile carbon sources (Cooper, 1990; Hill et al., 2000). Nitrogen uptake and retention in streams can be related to a variety of factors that differ among headwater streams including the amount of woody debris, leaf litter inputs, and shading (Vannote et al., 1980; Mullholland et al., 2000). Insect defoliations have been shown to significantly increase stream nitrate concentrations in the short-term (Swank et al., 1981; Eshleman et al., 1998), but may result in lower stream nitrate concentrations in the long term (Drohan and DeWalle, 2002).

\section{Conclusions}

We found bedrock geology to be the best predictor of summer and winter stream nitrate concentrations from 49 mid-Appalachian forested watersheds. Soil chemical 
parameters $(\mathrm{pH}, \mathrm{Ca}, \mathrm{P}, \% \mathrm{~N}$, and $\mathrm{C}: \mathrm{N})$ were not as important in explaining stream water nitrate. This may be because geology is more accurately mapped regionally than soils, and geologic chemistry is not as spatially variable as soil chemistry. The basal area of black locust, a nitrogen fixer, was a significant secondary predictor of summer stream nitrate. While black locust trees were not widely distributed, their presence in the riparian zone or in streamflow contributing areas appears to be sufficient to affect stream nitrate during the growing season. On an individual watershed basis, past land disturbances (agriculture) and stand age (old-growth) may be important in explaining stream nitrate concentrations. The portion of unexplained variation in stream nitrate concentrations may be attributed to differences in denitrification, hydrologic flow paths, in-stream $\mathrm{N}$ processing, and insect defoliation among the watersheds, which were not measured in this study and are difficult to assess at a regional scale. Our findings suggest that bedrock geology is an important factor to consider when explaining stream nitrate variation from forested watersheds, especially in unglaciated regions.

\section{Acknowledgments}

The authors would like to thank Pete Sharpe, Kevin McGuire, John Smith, Mike Gockley, Brandon Schreffler, and Patty Craig for assisting with field data collection. Thanks also go to Frederica Wood from the Fernow Experimental Forest and Linda White formally with the Monongahela National Forest; Paul Lilja, Dave Williams, and James Pflieger with the PA DCNR, Bureau of Forestry; Lysle Sherwin formerly with the Loyalhanna Watershed Association; Brent Pence with the Allegheny National Forest office; and Jeff Kochel with International Paper for help with watershed selection. William Sharpe, Peter Deines and Jon Chorover provided valuable comments on this manuscript. This research was supported by funds from the USDA Forest Service, Northeastern Experiment Station, Parsons, WV, and the USDA Water Science Fellowship program.

\section{References}

Aber, J. D., Nadelhoffer, K. J., Steudler, P. and Melillo, J. M.: 1989, 'Nitrogen saturation in northern forest ecosystems', Bioscience 39, 378-387.

Aber, J. D., McDowell, W., Nadelhoffer, K., Magill, A., Berntson, G., Kamakea, M., McNulty, S., currie, W., Rustad, L. and Fernandez, I.: 1998, 'Nitrogen saturation in northern forest ecosystems: Hypotheses revisited', Biosciences 48, 921-934.

Aber, J. D., Goodale, C. L., Ollinger, S. V., Smith, M., Magill, A. H., Martin, M. E., Hallett, R. A. and Stoddard, J. L.: 2003, 'Is nitrogen deposition altering the nitrogen status of northeastern forests?', Bioscience 53, 375-389.

Adams, M. B., Edwards, P. J., Wood, F. and Kochenderfer, J. N.: 1993, 'Artificial watershed acidification on the Fernow Experimental Forest, USA', J. Hydrol. 150, 505-519. 
Agren, G. I. and Bosatta, E.: 1988, 'Nitrogen saturation of terrestrial ecosystems', Environ. Pollut. 54, 185-197.

Alexander, M.: 1977, Introduction to Soil Microbiology, Wiley, New York, 467 pp.

Alriksson, A. and Olsson, M. T: 1995, 'Soil changes in different age classes of Norway Spruce (Picea abies (L.) Karst.) on afforested farmland', Plant Soil 168-169, 103-110.

American Public Health Association: 1995, Standard Methods for the Examination of Water and Wastewater, American Public Health Association, Washington, DC, pp. 481-489, 495496.

Baccanti, M., Magni, P., Oakes, W., Lake, J. and Szakas, T.: 1993, 'Application of an organic elemental analyzer for the analysis of nitrogen, carbon, and sulfur in soils', Am. Environ. Lab. 5, 16-17.

Berg, T. M. and Dodge, C. M.: 1981, Atlas of Preliminary Geologic Quadrangle Maps of Pennsylvania (Map 61), Pennsylvania Geologic Survey, Harrisburg, PA, USA.

Binkley, D. and Valentine, D.: 1991, 'Fifty-year biogeochemical effects of green ash, white pine, and Norway Spruce in a replicated experiment', For. Ecol. Manage. 40, 13-25.

Compton, J. E. and Boone, R. D.: 2000, 'Long-term impacts of agriculture on soil carbon and nitrogen in New England forests', Ecology 81, 2314-2330.

Cooper, A. B.: 1990, 'Nitrate depletion in the riparian zone and stream channel of a small headwater catchment', Hydrobiology 202, 13-26.

Dahlgren, R. A.: 1994, 'Soil acidification and nitrogen saturation from weathering of ammonium bearing rock', Nature 368, 838-840.

Dahlgren, R. A. and Driscoll, C. T.: 1994, 'The effects of whole-tree clearcutting on soil processes at the Hubbard Brook Experimental Forest, New Hampshire, USA', Plant Soil 158, 239-262.

Danso, S. K. A., Zapapta, F. and Awonaike, K. O.: 1995, 'Measurement of biological $\mathrm{N}_{2}$ fixation in field-grown Robinia pseudoacacia L.', Soil Biol. Biochem. 27, 415-419.

DeWalle, D. R. and Pionke, H. B.: 1996, 'Nitrogen export from forest land in the Chesapeake Bay region', in Proceedings of the 1994 Chesapeake Bay Research Conference, Edgewater, MD, USA, pp. 649-655.

DeWalle, D. R., Dinicola, R. S. and Sharpe, W. E.: 1987, 'Predicting baseflow alkalinity as an index to episodic stream acidification and fish presence', Water Resources Bull. 23, 29-35.

Dise, N. B. and Wright, R. F.: 1995, 'Nitrogen leaching from European forests in relation to nitrogen deposition', Forest Ecol. Manage. 71, 153-161.

Dise, N. B., Matzner, E. and Forsius, M.: 1998, 'Evaluation of organic horizon C:N ratio as an indicator of nitrate leaching in conifer forests across Europe', Environ. Pollut. 102, 453-456.

Drohan, P. J. and DeWalle, D. R.: 2002, 'Defoliation and atmospheric deposition influences on spring baseflow chemistry in 56 Pennsylvania mixed land-use watersheds', Water Air Soil Pollut. 133, $31-48$.

Edwards, P. J., Williard, K. W. J. and Kochenderfer, J. N.: 2004, 'Sampling considerations for establishment of baseline loadings from forested watersheds for TMDL application', Environ. Monitor. Assess. 98, 201-223.

Eshleman, K. N., Morgan, R. P., II, Webb, J. R., Deviney, F. A. and Galloway, J. N.: 1998. 'Temporal patterns of nitrogen leakage from mid-Appalachian forested watersheds: Role of insect defoliation', Water Resources Res. 34, 2005-2116.

Fenn, M. E., Poth, M. A., Aber, J. D., Baron, J. S., Bormann, B. T., Johnson, D. W., Lemly, A. D., McNulty, S. G., Ryan, D. F. and Stottlemyer, R.: 1998, 'Nitrogen excess in North American ecosystems: Predisposing factors, ecosystem responses, and management strategies', Ecol. Appl. 8, 706-733.

Gagnon, J. D.: 1965, 'Nitrogen deficiency in the York River burn, Gaspe, Quebec', Plant Soil 23, 49-59.

Gilliam, F. S., Adams, M. B. and Yurish, B. M.: 1996, 'Ecosystem nutrient responses to chronic nitrogen inputs at Fernow Experimental Forest, West Virginia', Can. J. For. Res. 26, 196-205. 
Godman, R. M. and Lancaster, K.: 1990, 'Tsuga canadensis (L.) Carr. Eastern hemlock', in R. M. Burns and B. H. Honkala (technical coordinators), Silvics of North America: 1. Conifers. Agriculture Handbook 654, vol. 2, USDA Forest Service, Washington, DC, pp. 604612.

Godman, R. M., Yawney, H. W. and Tubbs, C. H.: 1990, 'Acer saccharum Marsh. Sugar maple', in R. M. Burns and B. H. Honkala (technical coordinators), Silvics of North America: 2. Hardwoods. Agriculture Handbook 654, vol. 2, USDA Forest Service, Washington, DC, pp. 78-91.

Goodale, C. L. and Aber, J. D.: 2001, 'The long-term effects of land-use history on nitrogen cycling in northern hardwood forests', Ecol. Appl. 11, 253-267.

Goodale, C. L., Aber, J. D. and McDowell, W. H.: 2000, 'The long-term effects of disturbance on organic and inorganic nitrogen export in the White Mountains, New Hampshire', Ecosystems 3, 433-450.

Goyne, K. W.: 1998, 'Comparisons of soil solution chemistry and quantity from soil formed on contrasting geologic units', M.S. Thesis, Pennsylvania State University, State College, PA, USA, $230 \mathrm{pp}$.

Grier, C. C.: 1975, 'Wildfire effects on nutrient distribution and leaching in a coniferous ecosystem', Can. J. For. Res. 5, 599-607.

Gundersen, P., Callesen, I. and de Vries, W.: 1998, 'Nitrate leaching in forested ecosystems is related to forest floor C:N Ratios', Environ. Pollut. 102, 403-407.

Hill, A. R., Devito, K. J., Campagnola, S. and Sanmugadas, K.: 2000, 'Subsurface denitrification in a forest riparian zone: Interactions between hydrology and supplies of nitrate and organic carbon', Biogeochemistry 51, 193-223.

Holloway, J. M., Dahlgren, R. A., Hansen, B. and Casey, W. H.: 1998, 'Contributions of bedrock nitrogen to high nitrate concentrations in stream water', Nature 395, 785-788.

Hornbeck, J. W. and Lawrence, G. B.: 1996, 'Eastern forest fires can have long-term impacts on nitrogen cycling', in Proceedings of the 1996 Society of American Foresters Convention, Diverse Forests, Abundant Opportunities, and Evolving Realities, Albuquerque, NM, USA, November 1996, pp. 435-436.

Hornbeck, J. W., Martin, C. W., Pierce, R. S., Bormann, F. H., Likens, G. E. and Eaton, J. S.: 1987, 'The northern hardwood ecosystem: Ten years of recovery from clearcutting', USDA Forest Service, Northeastern Forest Experiment Station, NE-RP-596.

Huttl, R. F. and Schaaf, W.: 1995, 'Nutrient supply of forest soils in relation to management and site history', Plant Soil 168-169, 31-41.

Johnson, A. H. and Reynolds, R. C., Jr.: 1977, 'Chemical character of headwater streams in Vermont and New Hampshire', Water Resources Res. 13, 469-473.

Johnson, D. W. and Lindberg, S. E. (eds): 1992, Atmospheric Deposition and Forest Nutrient Cycling, Ecological Studies 91, Springer-Verlag, New York, 707 pp.

Lewis, G. P. and Likens, G. E.: 2000, 'Low stream nitrate concentrations associated with oak forests on the Allegheny High Plateau of Pennsylvania', Water Resources Res. 36, 3091-3094.

Lovett, G. M., Weathers, K. C. and Sobczak, W. V.: 2000, 'Nitrogen saturation and retention in forested watersheds of the Catskill Mountains, New York', Ecol. Appl. 10, 73-84.

Lovett, G. M., Weathers, K. C. and Arthur, M. A.: 2002, 'Control of nitrogen loss from forested watersheds by soil carbon: nitrogen ratio and tree species composition', Ecosystems 5, 712718.

Lynch, J. A. and Corbett, E. S.: 1991, 'Long-term implications of forest harvesting on nutrient cycling in Central Hardwood Forests', in L. H. McCormick and K. W. Gottschalk (eds), Proceedings of the Eighth Central Hardwood Forest Conference, USDA Forest Service, Northeastern Forest Experiment Station, General Technical Report NE-148, pp. 500-518.

Maryland Geological Survey: 1953, 'Geologic map of Garrett County, Maryland', Baltimore, MD, USA. 
Montagnini, F., Haines, B., Boring, L. and Swank, W.: 1986 'Nitrification potentials in early successional black locust and in mixed hardwood forest stands in the Southern Appalachians, USA', Biogeochemistry 2, 197-210.

Montagnini, F., Haines, B. and Swank, W. T.: 1991, 'Soil solution chemistry in black locust, pine/mixed-hardwoods and oak/hickory forest stands in the Southern Appalachians, USA', For. Ecol. Manage. 40, 199-208.

Mulholland, P. J., Tank, J. L. Sanzone, D. M., Wollheim, W. M., Peterson, B. J., Webster, J. R. and Meyer, J. L.: 2000, 'Nitrogen cycling in a forest stream determined by a ${ }^{15} \mathrm{~N}$ tracer addition', Ecol. Monogr. 70, 471-493.

Noether, G. E.: 1991, Introduction to Statistics: The Nonparametric Way, Springer-Verlag, New York, $414 \mathrm{pp}$.

Norris, V., Chen, M., Goldberg, M., Voskuil, J., McGurk, G. and Holland, I. B.: 1991, 'Calcium in bacteria: A solution to which problem?' Mol. Microbiol. 5, 775-778.

Ollinger, S. V., Smith, M. L., Martin, M. E., Hallet, R. A., Goodale, C. L. and Aber, J. D.: 2002, 'Regional variation in foliar chemistry and $\mathrm{N}$ cycling among forests of diverse history and composition', Ecol. 83, 339-355.

Pardo, L. H., Driscoll, C. T. and Likens, G. E.: 1995, 'Patterns of nitrate loss from a chronosequence of clear-cut watersheds', Water Air Soil Pollut. 85, 1659-1664.

Paul, E. A. and Clark, F. E. (eds): 1996, Soil Microbiology and Biochemistry, Academic Press, San Diego, CA, USA, 340 pp.

Peterjohn, W. T., Adams, M. B. and Gilliam, F. S.: 1996, 'Symptoms of nitrogen saturation in two Central Appalachian hardwood forest ecosystems', Biogeochemistry 35, 507-522.

Ponce, S. L., Sundeen, K. D. and Striffler, W. D.: 1979, 'Effect of selected geology-soil complexes on water quality of the Little Black Fork Creek', Report to USDA Forest Service, Northeast Forest Experiment Station, 96 pp.

Raison, R. J.: 1979, 'Modification of the soil environment by vegetation fires, with particular reference to nitrogen transformations: A review', Plant Soil 51, 73-108.

Reger, D. B.: 1923, Tucker County, West Virginia, Geological Survey, Wheeling News Litho. Co., Wheeling, WV, USA.

Reger, D. B.: 1931, Randolph County, West Virginia, Geological Survey, West Virginia University, Morgantown, WV, USA.

Riha, S. J., Campbell, G. S. and Wolfe, J.: 1986, 'A model of competition for ammonium among heterotrophs, nitrifiers, and roots', Soil Sci. Soc. Am. J. 50, 1463-1466.

Ross, D.: 1995, 'Recommended methods for determining soil cation exchange capacity', in J. T. Sims and A. Wolf (eds), Recommended Soil Testing Procedures for the Northeastern United States, Northeast Regional Bulletin \#493, Agricultural Experiment Station, University of Delaware, Newark, DE, USA, pp. 57-62.

SAS Institute Inc.: 1985, SAS User's Guide: Statistics, Version Fifth Edition, SAS Institute Inc. Cary, NC, USA, 956 pp.

Schimel, J. P. and Firestone, M. K.: 1989, 'Nitrogen incorporation and flow through a coniferous forest soil profile', Soil Sci. Soc. Am. J. 53, 779-784.

Schlesinger, R. C.: 1990, 'Fraxinus americana L. White ash', in R. M. Burns and B. H. Honkala (technical coordinators), Silvics of North America: 2. Hardwoods. Agriculture Handbook 654, vol. 2, USDA Forest Service, Washington, DC, pp. 333-338.

Silsbee, D. G. and Larson G. L.: 1982, 'Water quality of streams in the Great Smoky Mountains National Park', Hydrobiology 89, 97-115.

Sims, J. T. and Eckert, D.: 1995, 'Recommended Soil pH and Lime Requirement Test' in J. T. Sims and A. Wolf (eds), Recommended Soil Testing Procedures for the Northeastern United States, Northeast Regional Bulletin \#493, Agricultural Experiment Station, University of Delaware, Newark, DE, USA. 
Smith, R. J.: 1995 'Calcium and bacteria', Adv. Microb. Physiol. 37, 83-133.

Stednick, J. D. and Kern, T. J.: 1992, 'Long-term effects of timber harvesting in the Oregon coast range: The New Alsea Watershed Study (NAWS)', in Interdisciplinary Approaches in Hydrology and Hydrogeology, American Institute of Hydrology, St. Paul, MN, pp. 502510.

Stoddard, J. L.: 1994, 'Long-term changes in watershed retention of nitrogen: Its causes and aquatic consequences', in L. A. Baker (ed), Environmental Chemistry of Lakes and Reservoirs, Advances in Chemistry, Series No. 237, American Chemistry Society, Washington, DC, pp. 223-284.

Swank, W. T., Waide, J. B., Crossley, D. A., Jr. and Todd, R.: 1981, 'Insect defoliation enhances nitrate export from forest ecosystems', Oecologia 51, 297-299.

Taylor, L. E., Werkheiser, W. H. and Kriz, M. L.: 1983, 'Groundwater resources of the West Branch Susquehanna River basin, Pennsylvania', Water Resources Report 56, Pennsylvania Geological Survey, Fourth Series, Harrisburg, PA, USA.

Taylor, L. E., Werkheiser, W. H., duPont, N. S. and Kriz, M. L.: 1982, 'Groundwater resources of the Juniata River basin, Pennsylvania', Water Resources Report 54, Pennsylvania Geological Survey, Fourth Series, Harrisburg, PA, USA.

Van Miegroet, H. and Cole, D. W.: 1984, 'The impact of nitrification on soil acidification and cation leaching in a red alder forest', J. Environ. Qual. 13, 586-590.

Vannote, R. L. Minshall, G. W., Cummins, K. W., Sedell, J. R. and Cushing, C. E.: 1980, 'The river continuum concept', Can. J. Fish. Aquat. Sci. 37, 130-137.

Vitousek, P. M. and Reiners, W. A.: 1975, 'Ecosystem succession and nutrient retention: A hypothesis', Bioscience 25, 376-381.

Webb, J. R., Cosby, B. J., Deviney, F. A., Jr., Eshleman, K. N. and Galloway, J. N.: 1995, 'Change in the acid-base status of an Appalachian mountain catchment following forest defoliation by gypsy moth', Water Air Soil Pollut. 85, 535-540.

Wenger, K. F. (ed): 1984, Forestry Handbook, Wiley, New York, 1335 pp.

Wentworth, C. K.: 1930, 'A simplified method of determining the average slope of land surfaces', Am. J. Sci. 20, 184-194.

Williard, K. W. J., DeWalle, D. R., Edwards, P. J. and Schnabel, R. R.: 1997, 'Indicators of nitrate export from forested watersheds of the mid-Appalachians, United States of America', Global Biogeochem. Cycles 11, 649-656.

Williard, K. W. J., DeWalle, D. R. and Edwards, P. J.: 2003, 'Assessing the extent of nitrogen saturation in northern West Virginia forested watersheds: A survey of stream nitrate concentrations', in J. W. Van Sambeek, J. O. Dawson, F. Ponder, Jr., E. F. Loewenstein and J. S. Fralish (eds), Proceedings of the Thirteenth Central Hardwood Forest Conference, Urbana, IL, USA, 1-3 April 2002, General Technical Report NC-234, US Department of Agriculture, Forest Service, North Central Research Station, St. Paul, MN, pp. 121-129.

Wolfe, A. and Beegle, D.: 1995, 'Recommended soil tests for macronutrients: Phosphorus, potassium, calcium, and magnesium', in J. T. Sims and A. Wolf (eds), Recommended Soil Testing Procedures for the Northeastern United States, Northeast Regional Bulletin \#493, Agricultural Experiment Station, University of Delaware, Newark, DE, USA, pp. 25-34. 